\title{
Climatic Relationships of Permafrost Zones in Areas of Low Winter Snow-Cover
}

\author{
STUART A. HARRIS
}

\begin{abstract}
In areas with under $50 \mathrm{~cm}$ snow cover in winter, the permafrost zones show diagnostic long term freezing indices and thawing indices. The warmer boundary of the zone of continuous permafrost traverses the mean annual air temperature (MAAT). The boundary between discontinuous and sporadic permafrost lies just on the cold side of $0^{\circ} \mathrm{C}$ MAAT. The sporadic permafrost zone includes the zone of ice caves and the regions with patches of ice beneath ponds and peatbogs, extending to $5^{\circ} \mathrm{C}$ MAAT at a thawing index of 4000 degree days per year. The relationship is applicable to Norway, Iceland, Spitzbergen, Canada and the People's Republic of Mongolia.

There are some marked variations in lapse rate from one environment to another, the most marked of which occurs above tree line where the lapse rate increases markedly in winter, though not in summer. This produces a change in MAAT of $2.5^{\circ} \mathrm{C}$ on Plateau Mountain. The changes also occur at some points in non-permafrost areas and it appears likely that they are due to spatial and seasonal changes in albedo. Whatever the cause, the variations in lapse rate indicate that calculations of past world climatic change based on data from one area may be misleading.
\end{abstract}

RÉSUMÉ. Dans les aires couvertes par moins de $50 \mathrm{~cm}$ de neige en hiver, les zones de pergélisol sont définies par les indices de gel et de dégel. La limite du front chaud de la zone de pergélisol continue recoupe la courbe de la moyenne annuelle de la température de l'air (MATA). La limite entre le pergélisol discontinu et le pergélisol sporadique se trouve juste du côté froid de la courbe $0^{\circ} \mathrm{C}$ MATA. La zone du pergélisol sporadique inclut la zone des glacières naturelles et les régions avec des lentilles de glace en-dessous des étangs et des tourbières, et s'étend jusqu'à $5^{\circ} \mathrm{C}$ MATA, pour un indice de dégel de 4000 degrés-jour par année. Cette relation tient en Norvège, en Islande, au Spitzberg, au Canada, et pour la République populaire de Mongolie.

Il y a quelques variations marquées dans le taux d'écart d'un environnement à un autre. La variation la plus marquée survient au-dessus de la limite des arbres où le taux d'écart croit d'une façon marquée en hiver, mais pas en été. Ceci produit un changement de $2,5^{\circ} \mathrm{C}$ MATA à "Plateau Mountain". Ces changements se produisent aussi à quelques endroits dans les aires avec absence de pergélisol et il paraît probable qu'ils soient dus à des changements spatiaux et saisonniers dans l'albedo. Qu'elle qu'en soit la cause, les variations du taux d'écart indiquent que les calculs des changements climatiques anciens dans le monde, basés sur des données limitées à une seule aire, pourraient être trompeurs.

Traduit par Ian Badgley, Université du Québec à Montréal.

\section{INTRODUCTION}

The most extensive areas of permafrost are found in the large northern countries of the world, viz., Canada, China, and the U.S.S.R. As a result of the vast areas to be mapped, there is a severe problem in delimiting its distribution in many areas, e.g. the Rocky Mountains of North America. Given adequate technological help (e.g. Harris and Brown, 1978), the permafrost distribution can be determined in localized areas, but producing a detailed map of its distribution along the Rocky Mountains remains a formidable task.

Clearly, it is necessary to develop a reconnaissance tool capable of predicting the possible distribution of permafrost in large areas of mountainous terrain, so that these predictions can be checked on the ground. Since the usual diagnostic features of lowland permafrost regions (pingos, palsas, patterned ground, etc.) are either absent or unobtrusive in mountainous terrain, air photo-interpretation is not a complete answer. Climate is the major determinant of permafrost (Ferrians and Hobson, 1973) and although other factors are involved (see for example Brown, 1973), it still holds the best possibilities for this type of prediction at a reconnaissance scale. This paper discusses a new method of climatic prediction for specific conditions which are fairly widespread in permafrost regions. It then examines the spatial variation of some climatic data from semi-desert to permafrost regions in parts of western North America.

\section{PAST WORK}

Many attempts have been made to match climatic parameters with the distribution of the features associated with permafrost. Black (1951) realized the difficulty of the problem when he used a 0 to $-3^{\circ} \mathrm{C}$ mean annual air temperature (MAAT) as a characteristic of permafrost regions. Subsequently, Nichols (1956) noted a MAAT of $-2.6^{\circ} \mathrm{C}$ for a permafrost location in the discontinuous zone. Kaiser (1960) claimed that the limit of continuous permafrost in Siberia was bounded by the $-2^{\circ} \mathrm{C}$ mean annual isotherm, although others have suggested different values.

In Canada, Pihlainen (1962) placed the southern boundary of permafrost at between -1.1 and $-3.9^{\circ} \mathrm{C}$ MAAT. However, Reduzobov (1954), Péwé (1956), Brown (1967a), Brown and Péwé (1973) and others have concluded that the boundary approximated the $-1{ }^{\circ} \mathrm{C}$ MAAT isotherm. In an earlier discourse, Brown (1960) concluded that there was no close correlation between permafrost and air temperature in Canada and the U.S.S.R. Subsequent studies of the boundaries have tended to support this conclusion, but it has also become obvious that there are some very important factors that interfere with a simple climatic relationship (Brown, 1973). These include 
depth of snow cover, vegetation, hydrology, lithology and topography.

Sanger (1966) and Thompson (1966) have discussed the importance of degree-days in engineering studies, while others (Brown, 1960; Washburn, 1973) have published maps of freezing and thawing indices based on mean daily temperatures below and above the freezing point respectively. Unfortunately these have not previously been correlated with observations of the occurrence of permafrost. It is the possibility of this relationship that will be studied below.

\section{LIMITING CONDITIONS}

If the MAAT is plotted against elevation for the Class $\mathrm{A}$ weather stations between latitudes $50^{\circ}$ and $52^{\circ} \mathrm{N}$ in southern Alberta, the results show considerable scatter (Fig. 1).

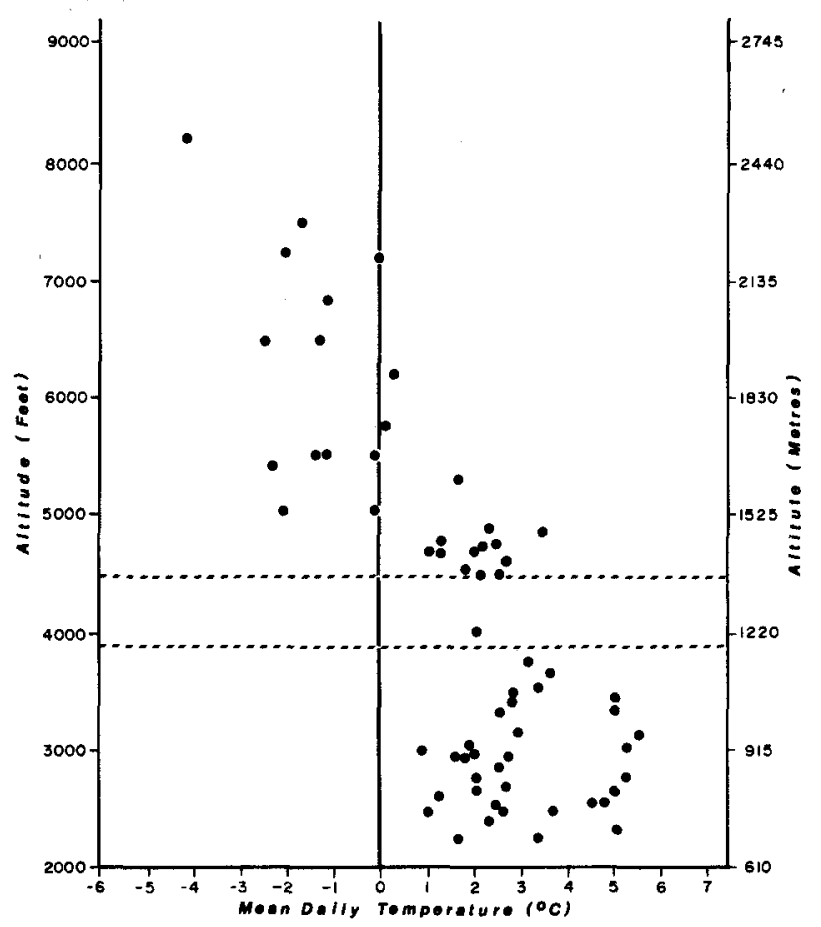

FIG. 1. Mean annual air temperature versus altitude for all the Class A weather stations between $50^{\circ}$ and $52^{\circ} \mathrm{N}$ in Alberta. The boundaries of the Parkland vegetation zone are indicated by the dashed lines around 1210 and $1350 \mathrm{~m}$ altitude.

If the mean annual air temperature is plotted against the ground temperature at the surface of the zone of zero annual amplitude, again the predictive ability is poor, even though the correlation is obvious (Fig. 2). However, if we examine the geotherms for a given site (Fig. 3), there are clearly two basic waves of energy flow into and out of the soil. Although chinooks are common in Calgary, their effect is dwarfed by the seasonal effects of heating in summer and cooling in winter. Thus, the concept of using freezing and thawing indices appears to be basically sound.

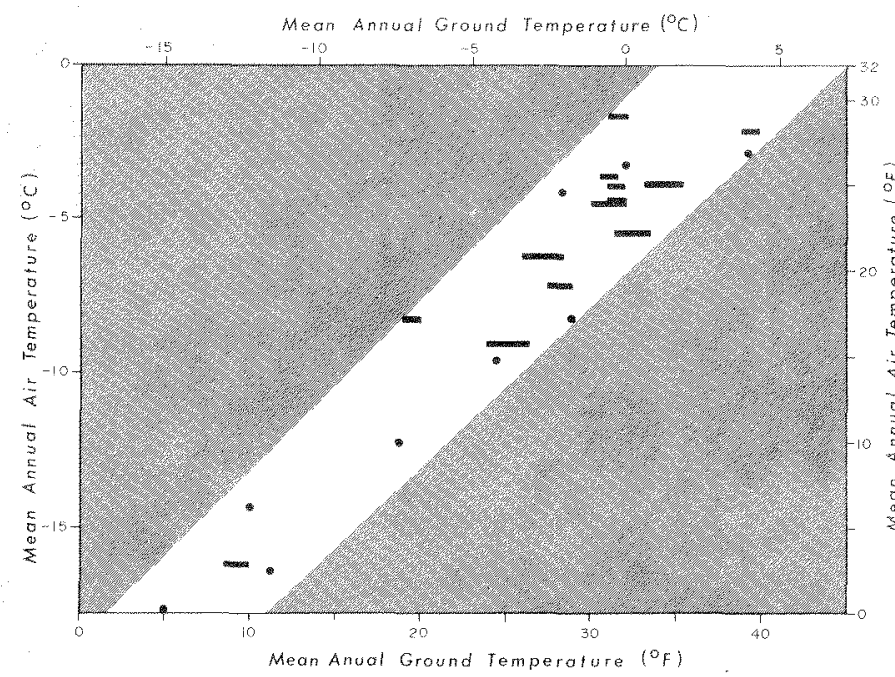

FIG. 2. Mean annual air temperature versus ground temperature at the top of the zone of zero annual amplitude (after Brown, 1967a; Smith, 1975; Harris and Brown, 1978).

It is well known that a thick snow cover acts as an insulating layer, preventing the cold from penetrating the ground (Krinsley, 1963; Brown, 1973; Harris and Brown, 1978; Nicholson, 1976, 1978a). The critical question is what thickness of snow inhibits winter cold penetration into the upper layers of the soil so that only seasonal frost will be present. We have data from a number of sites at the margin of permafrost at Plateau Mountain showing varying thicknesses of snow cover in January, February, and March (Fig. 4). The critical thickness appears to be 50 $\mathrm{cm}$ in southern Alberta at a freezing index of about 2250 degree-days/year and a thawing index of about 750 degreedays/year. Thus the freezing and thawing indices can only be expected to yield consistent results in predicting the presence or absence of permafrost where the average winter snow cover does not exceed $50 \mathrm{~cm}$. This is only important in the higher altitudinal zones along the Pacific Coast and in Québec; it does, however, explain why permafrost is sporadic over such a wide area of Québec (Brown, 1975).

The experience of Brown (1973) with lithological, hydrological, topographic, and biological factors must also be borne in mind, but is not too serious as long as peaty deposits are treated separately from mineral soils. Wet sites also differ appreciably from dry sites. However, the permafrost maps accommodate the variability by using continuous, discontinuous and sporadic classes on maps (see the discussion in Harris, 1979).

\section{PERMAFROST ZONES AND FREEZE-THAW INDICES}

The permafrost zones in parts of Canada were provisionally mapped by Brown (1967a) and have been reexamined in Québec by Brown (1975) and Nicholson (1978b), and in the prairies by Zoltai (1971). A start on the detailed distribution in the Rockies has been made by 


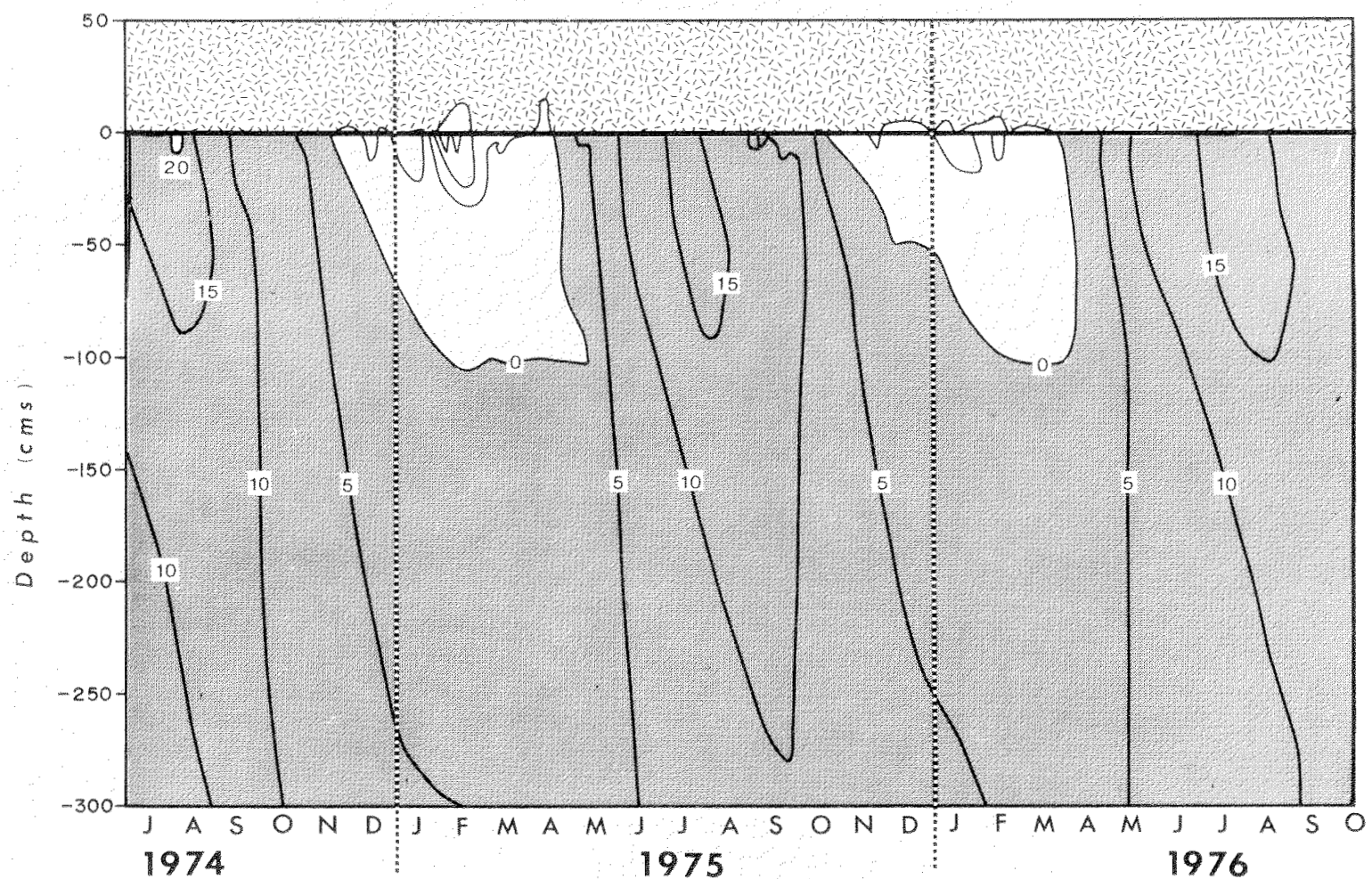

FIG. 3. Geotherms for the soil at the University of Calgary weather station.

Brown (1967b), Crampton (1977, 1978), Harris and Brown (1978) and Harris (1979).

Figure 5 shows the results of plotting freezing indices against thawing indices for Canadian stations where there is less than $50 \mathrm{~cm}$ of snow cover between December and March. The type of permafrost zone for each site is also indicated and it will be seen that the data plot in discrete zones. Included in the data points are information from Iceland (Priesnitz and Schunke, 1978), Spitzbergen (Jahn,

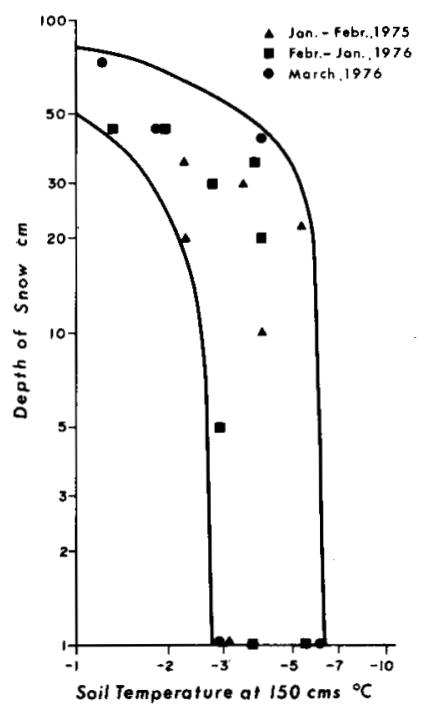

FIG. 4. Winter soil temperature at a depth of $150 \mathrm{~cm}$ as related to depth of snow on Plateau Mountain (after Fig. 9, Harris and Brown, 1978; reproduced with permission).
1976; Norske Meteorologiske Institutt, 1963-74), Norway (Ahman, 1977; Norske Meteorologiske Institutt, 1963-74), and the Mongolian People's Republic (Gavrilova, 1978; Gravis et al., 1978). The data from different countries and observers agree very well.

The continuous permafrost zone in Figure 5 is bounded by a curve which transgresses the isotherms of mean annual temperature, which explains why the literature from different areas is confusing. The zone of discontinuous permafrost extends almost to the $0^{\circ} \mathrm{C}$ isotherm. Beyond it lies a zone of sporadic permafrost in which some sites show either ice caves or patches of ice beneath lakes or in peatlands. The zones of ice caves and ice patches in wet places appear to be coincident. Clearly more attention will need to be paid to this zone in future. The zone of ice caves in Eurasia has yet to be mapped, but is fairly widespread, e.g. ice caves occur in the Crimea.

\section{NEAR-SURFACE LAPSE RATES}

If freeze-thaw indices are the key to the climatology of the permafrost zones, they can also be used to check the validity of the concept that near-surface temperatures change at a constant rate with climatic change. Such an assumption is needed in predicting world-wide climatic changes using evidence of climatic changes at a single location, and is widely used in palaeoclimatic interpretations. It was also the basis of the earlier work of Brown (1967a). 


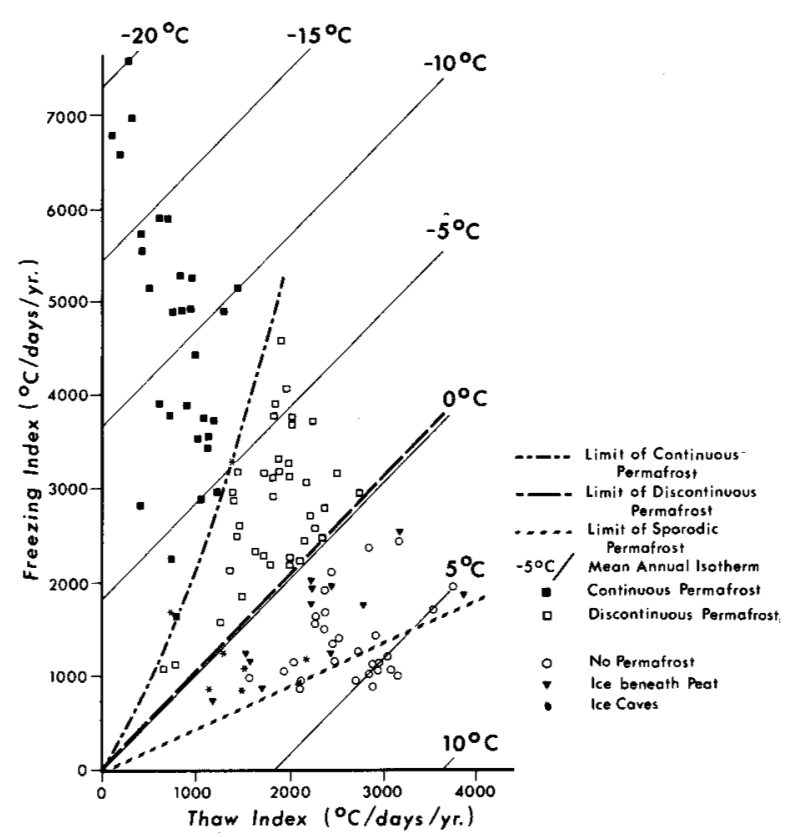

FIG. 5. The relationship between occurrence of permafrost zone and the plot of freezing index versus thawing index for stations in Canada, Norway, Spitzbergen, Iceland and the Mongolian People's Republic. The indices are based on a minimum of two years' data and usually 10-25 years.

If the lapse rate is constant, then the plot of freezing and thawing indices along a line of latitude should plot as a straight line on the freezing index-thawing index plot. However, when the 1974-75 indices for the weather stations lying along the $50^{\circ} \mathrm{N}$ parallel from Medicine Hat (MH) to Plateau Mountain (PM) in Southern Alberta are plotted as in Figure 5, they plot in a dog-legged form with a marked change occurring at about the boundary of the sporadic and discontinuous permafrost zones (Fig. 6). Similarly, the 1974-75 data for the stations lying along a line from Medicine Hat via Edmonton, Great Slave Lake to Inuvik (Fig. 7) were plotted on the same diagram. Once again a series of straight lines appeared. Clearly, lapse rates vary abruptly from place to place at certain points on the landscape in a manner not previously considered.

Figure 8 shows the results of plotting the freezing indices and thawing indices against altitude for the data between Medicine Hat and Plateau Mountain. The thawing index shows a moderate scatter but the data can be approximated by a straight line. However, the freezing index shows an abrupt change above the upper tree line. Here the lapse rate increases considerably, but there are insufficient data to establish the exact slope of the new rate.

Figure 9 shows a similar plot for the Medicine HatInuvik 1974-75 data, using latitude in place of altitude. Once again, abrupt breaks occur. In the case of the thawing index, the first break occurs at the boundary between the forest and agricultural zones near Edmonton and again in the Lower MacKenzie Valley. The data were corrected

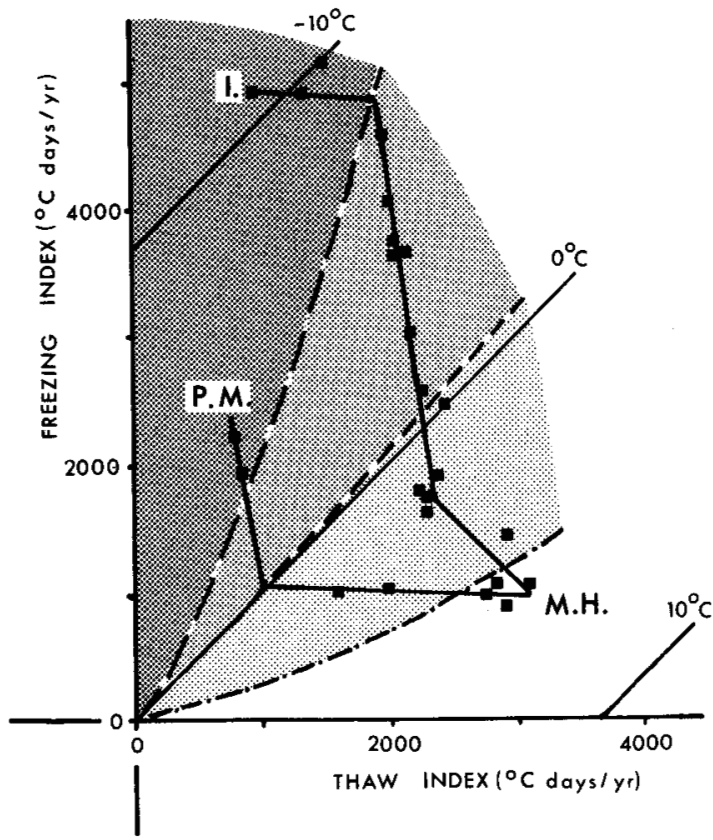

FIG. 6. Weather station data for 1974 and 1975 along traverses from Medicine Hat (MH), along the parallel to Plateau Mountain (PM) and north-northwestward to Inuvik (I), plotted on freezing-thawing index diagrams. Note the abrupt changes in the lines, indicating changes in lapse rate.

for the effects of elevation above sea level but the changes in slope of the lines remained. The only modification encountered was that the change of slope for the stations along the Lower MacKenzie Valley moved so as to approximate the position of the tundra-forest boundary and the commencement of the slope to the Arctic Ocean.

The freezing index is even more complex, showing breaks near the tundra-forest boundary and the Arctic Ocean, as well as near Lesser Slave Lake and the HannaDrumheller area. The latter is the boundary between the

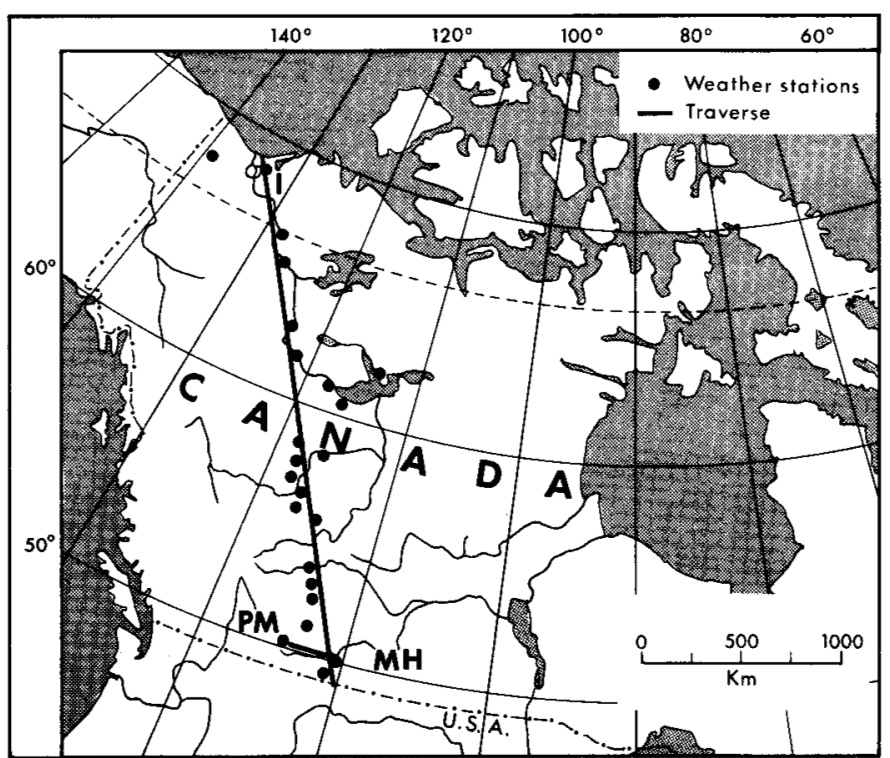

FIG. 7. Positions of the weather stations used on the traverse in Fig. 6. 
agricultural zone and the badlands along the Red Deer River.

If vegetational boundaries are critical, we should reexamine the thawing index data for the Medicine HatPlateau Mountain traverse. Figure 10 shows an alternative

A.
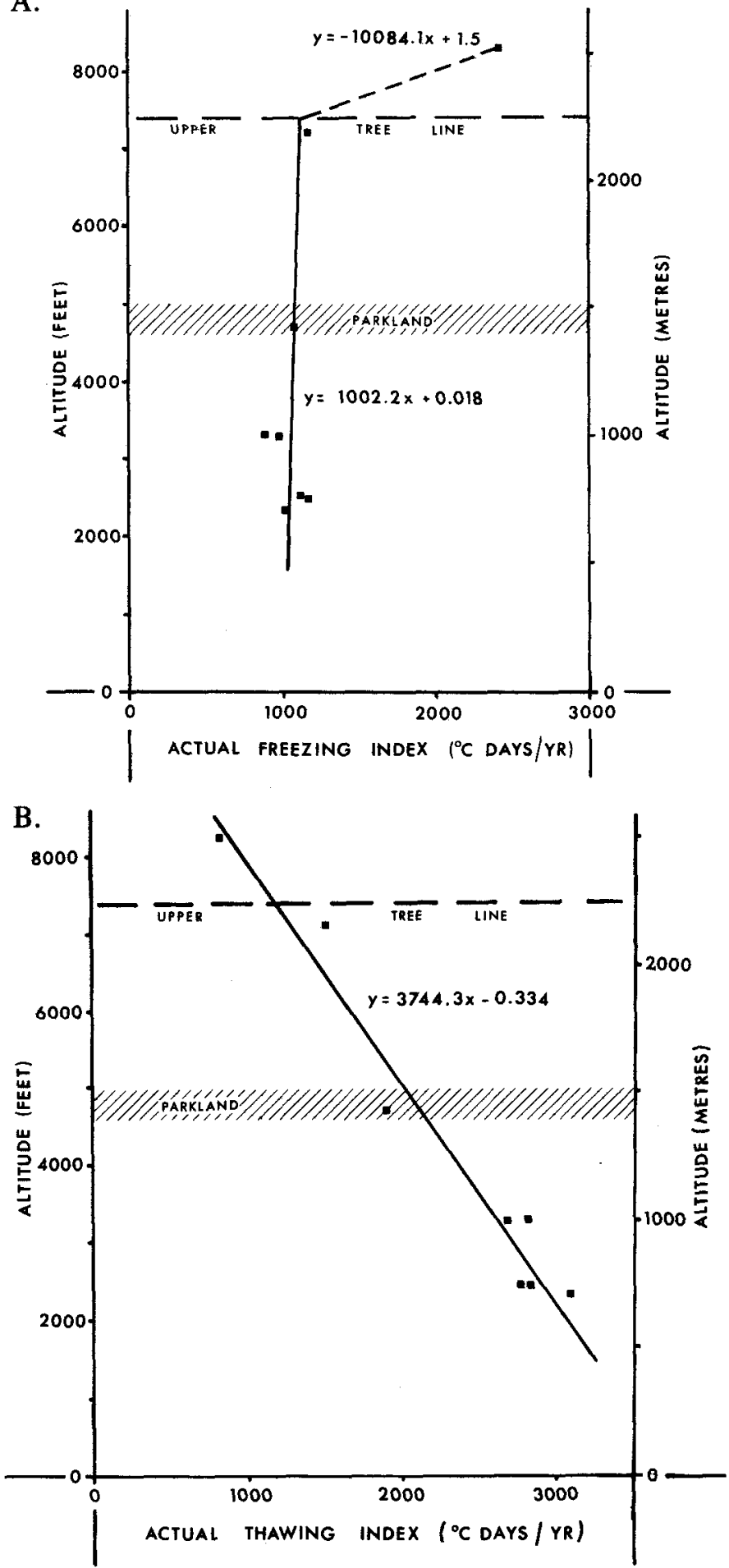

FIG. 8. Results of plotting freezing indices (A) and thawing indices (B) against altitude for the 1974-75 data from the Medicine Hat-Plateau Mountain traverse. Note that although " $x$ " and " $y$ " are used, it is doubtful whether either are independent variables. interpretation of the data with breaks at the boundaries of the treed zone. The lines fit the data points much better but obviously we need more information. An extra four weather stations have recently been added to this traverse in the zone above $1500 \mathrm{~m}$ to determine which (if either) of the interpretations is correct.

The major point remains: abrupt changes occur in nearsurface lapse rates at certain specific boundaries which are often related to vegetation cover. These boundaries are different in summer and winter. Troll (1943) examined data for South America which showed similar breaks but he missed them by concentrating on frequency of freezing and thawing.

Recently Fuji and Higuchi (1976) have noted similar changes in lapse rates in Nepal. Fuji concluded orally at Edmonton in July, 1978 that the permafrost in the ground might cause the large increase in lapse rate above the permafrost level on mountains. However, this is unlikely for three reasons. First, the supply of heat from the ground is up to three orders of magnitude smaller than the radiation received from the sun, apart from advection by air masses. Second, similar breaks occur below the permafrost boundary and in non-permafrost areas in lowlands. Third, the most obvious break occurs in winter, not in summer.

The other most likely cause of the abrupt changes in seasonal lapse rates is the change of albedo from place to place. Angström (1916) has pointed out the tremendous difference in amount of insolation reaching the ground between bare ground and prairie, while other marked differences occur between these environments and forest. The change from summer to winter brings about further changes in albedo, causing some environments to have similar albedos for winter while being very different in albedo in summer. This possible cause is under further study, but the fact remains that a change in vegetation cover can produce an instantaneous change in mean annual temperature and near-surface lapse rate. At Plateau Mountain, the change from forest to alpine zone appears to be accompanied by a drop in MAAT of $2.5^{\circ} \mathrm{C}$, caused by the increase in the lapse rate in winter.

\section{CONCLUSIONS}

For stations with less than $50 \mathrm{~cm}$ of snow cover from December to March in the Northern Hemisphere, the permafrost zones are defined by the long term averages for freezing indices and thawing indices as in Figure 5. Given these meteorological indices, the probability of finding permafrost can be estimated. This relationship fits the data from Norway, Iceland, the People's Republic of Mongolia, and from Canada.

The boundary of the continuous permafrost zone crosses the isotherms for MAAT, explaining much of the con- 
A.

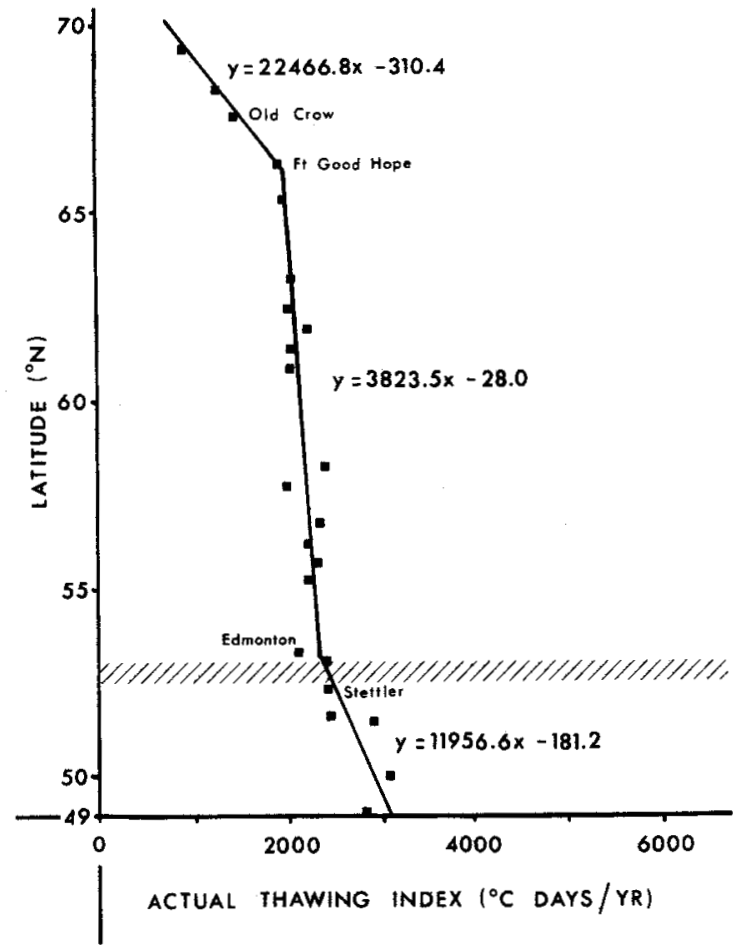

C.

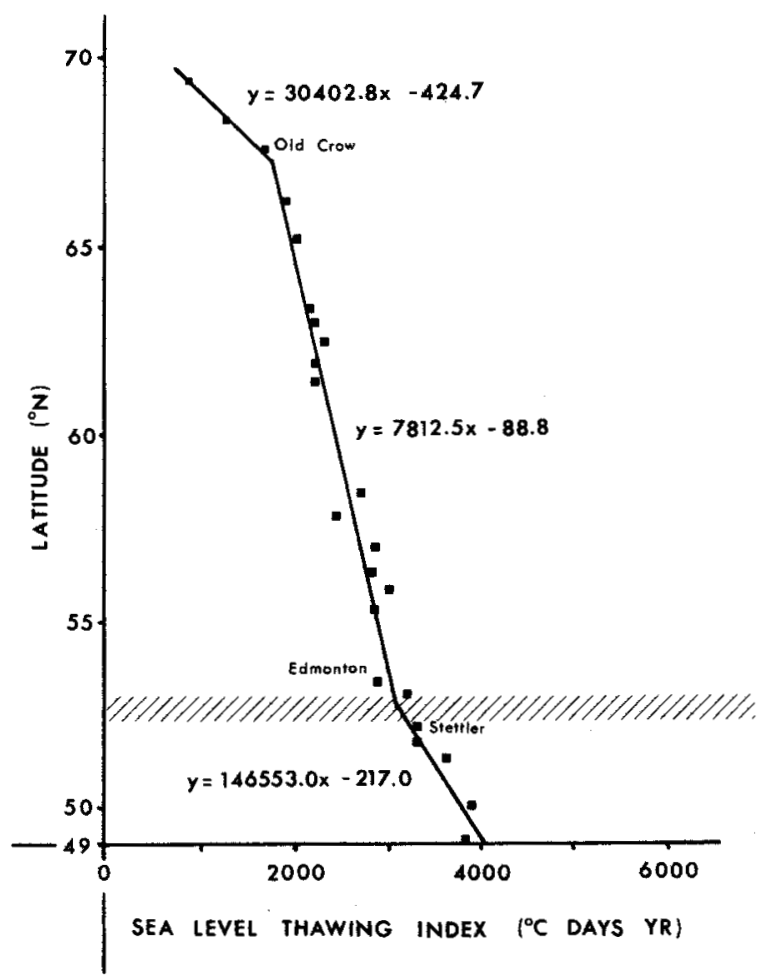

flicting evidence from different areas that has been described in the past. The outer boundary for the discontinuous permafrost zone lies on the cold side of the $0^{\circ} \mathrm{C}$ MAAT isotherm. There is also a broad zone of sporadic permafrost characterized by patches of ice beneath ponds and in peaty deposits which occupy a similar thermal zone to that of scattered ice caves.
B.

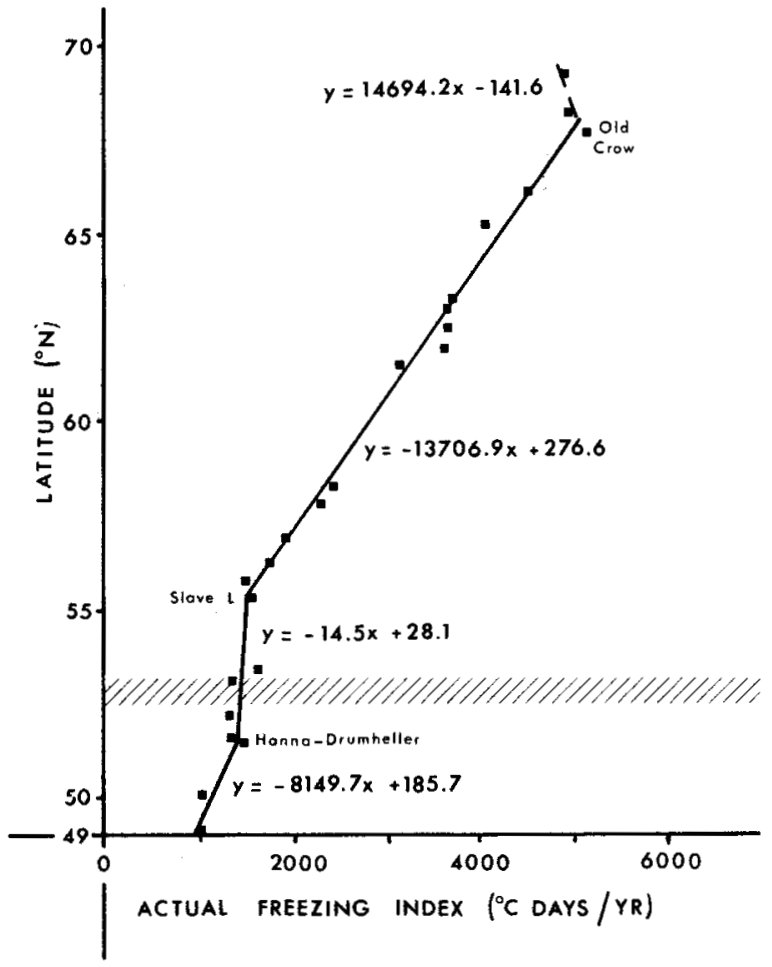

FIG. 9. Results of plotting the actual thawing indices (A), the freezing indices (B), and the sea level adjusted thawing indices (C) against altitude for the 1974-75 data from the Medicine Hat-Inuvik traverse.

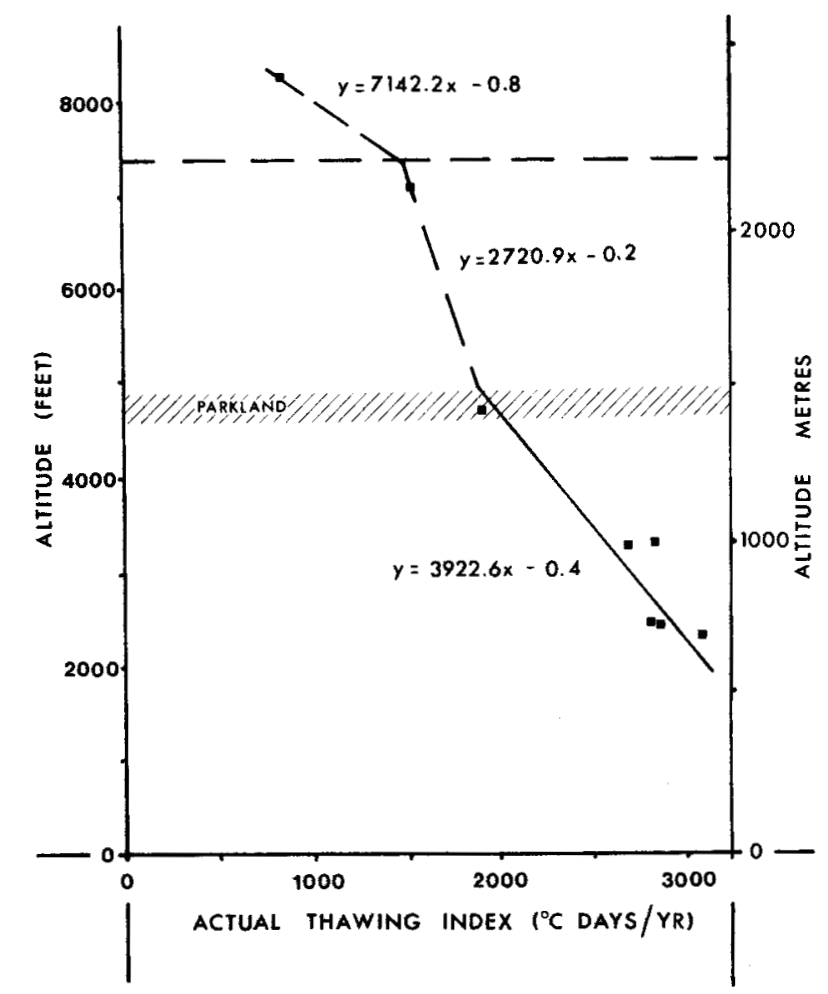

FIG. 10. An alternative interpretation of the thawing indices for the Medicine Hat-Plateau Mountain 1974-75 data, assuming that the major vegetation zones may have distinctive lapse rates.

Although most studies of palaeoclimatic change assume a constant lapse rate everywhere, there are some marked variations from one environment to another. The most 
marked occurs above the tree line where the lapse rate increases very substantially in winter, though not in summer. This produces a change of MAAT of $2.5^{\circ} \mathrm{C}$ on Plateau Mountain. The lapse rates in summer and winter behave independently, so that the MAAT averages and partially camouflages the changes. The changes in lapse rates also occur at some points in non-permafrost areas and it appears likely that they are due to spatial and seasonal changes in albedo.

\section{ACKNOWLEDGEMENTS}

Drs. R. Ahman, R. J. E. Brown, Anders Rapp, and S. C. Zoltai all discussed details of the discontinuous permafrost boundaries in their field areas. The work was aided in part by N.R.C. grant \#A-7843.

\section{REFERENCES}

AHMAN, R. 1977. Palsar i Nord Norge. Meddelander Frän Lunds Universitets Geografiska Institution Avhandingar 78. $165 \mathrm{p}$.

ANGSTRÖM, A. 1916. Über die Gegenstrahlung der Atmosphäre. Meteorologische Zeitschrift 33:529-538.

BLACK, R.F. 1951. Permafrost. Smithsonian Institution Report 1950. 273-301.

BROWN, R.J.E. 1960. The distribution of permafrost and its relation to air temperature in Canada and the U.S.S.R. Arctic 13(3):163-177.

1967a. Permafrost in Canada. Geological Survey of Canada Map 1246a. Division of Building Research, National Research Council of Canada. Publication NRC 9769.

1967b. Permafrost investigations in British Columbia and Yukon Territory. Division of Building Research, National Research Council of Canada Technical Paper No. 253. 55 p.

1973. Influence of climatic and terrain factors on ground temperatures at three locations in the permafrost region of Canada. In: Permafrost, The North American Contribution to the Second International Conference on Permafrost, Yakutsk, Siberia. National Academy of Sciences, Washington, D.C. 27-34.

1975. Permafrost investigations in Québec and Newfoundland. Division of Building Research, National Research Council of Canada Technical Paper No. 449. $36 \mathrm{p}$.

and PÉWÉ, T.L. 1973. Distribution of permafrost in North America and its relationship to the environment: A review, 1963-1973. In: Permafrost, The North American Contribution to the Second International Conference on Permafrost, Yakutsk, Siberia. National Academy of Sciences, Washington, D.C. 71-100.

CRAMPTON, C.B. 1977. Changes in permafrost distribution in northeastern British Columbia. Arctic 30(1):61-62.

1978. The distribution and thickness of icy permafrost in northeastern British Columbia. Canadian Journal of Earth Sciences 15:655-659.

FERRIANS, O.J. Jr. and HOBSON, G.D. 1973. Mapping and predicting permafrost in North America: A review, 1963-1973. In: Permafrost, The North American Contribution to the Second International Conference on Permafrost, Yakutsk, Siberia. National Academy of Sciences, Washington, D.C. 479-498.

FUJI, Y. and HIGUCHI, K. 1976. Ground temperature and its relation to permafrost occurrences in the Kimbu Himal and Hidden Valley, Nepal Himalayas. Glaciers and Climates of Nepal Himalayas: Report of the Geological Expedition to Nepal. Seppyo 38(Special Issue):125128.

GAVRILOVA, M.H. 1978. Climatic (heat balance) factors governing formation of permafrost in the Mongolian People's Republic. In: U.S.S.R. Contribution, Permafrost, Second International Conference. National Academy of Sciences Translations, Washington, D.C. 35-37.
GRAVIS, G.F., ZABOLOLNIK, S.I., LISUN, A.M. and SUKHODROVSKII, V.L. 1978. The geocryological characteristics of the Mongolian People's Republic and some characteristics of permafrost development in the past. In: U.S.S.R. Contribution, Permafrost, Second International Conference. National Academy of Sciences Translations, Washington, D.C. 81-86.

HARRIS, S.A. 1979. Ice caves and permafrost zones in southwest Alberta. Erdkunde 33:61-70.

and BROWN, R.J.E. 1978. Plateau Mountain: A case study of alpine permafrost in the Rocky Mountains. In: Proceedings of the Third International Conference on Permafrost, Edmonton, Alberta. Vol. 1:385-391.

JAHN, A. 1976. Contemporaneous geomorphological processes in Longyeardalen, Vestispitzbergen (Svalbard). Buil. Peryglacjalny 26:253-268.

KAISER, K. 1960. Klimazeugen des periglazialen Dauerfrostbodens in Mittel und Westeuropa. Eiszeitalter und Gegenwort 11:121-141.

KRINSLEY, D.B. 1963. Influence of snow cover on frost penetration. U.S. Geological Survey Professional Paper 475-B. Washington, D.C. B144-B147.

NICHOLS, D.R. 1956. Permafrost and ground-water conditions in the Glennallen area, Alaska. Manuscript on open file. U.S. Geological Survey, Washington, D.C., Anchorage, Alaska and College, Alaska.

NICHOLSON, F.H. 1976. Permafrost thermal amelioration tests near Schefferville, Québec. Canadian Journal of Earth Sciences 13:1694 1705.

1978a. Permafrost modification by changing the natural energy budget. In: Proceedings of the Third International Conference on Permafrost, Edmonton, Alberta. Vol. 1:61-67.

1978b. Permafrost distribution and characteristics near Schefferville, Quebec: Recent studies. In: Proceedings of the Third International Conference on Permafrost, Edmonton, Alberta. Vol. 1:427433.

Norske Meteorologiske Institutt. 1963-1974 Norske Meteorologiske Arbok. Oslo: Kommisjon Hos H. Aschehoug and Co. A/S.

PÉẂE, T.L. 1966. Permafrost and Its Effect on Life in the North. Corvallis, OR: Oregon State University Press. 40 p.

PIHLAINEN, J.A. 1962. An approximation of probable permafrost occurrence. Arctic 15(2):151-154.

PRIESNITZ, K. and SCHUNKE, E. 1978. An approach to the ecology of permafrost in central Iceland. In: Proceedings of the Third International Converence on Permafrost, Edmonton, Alberta. Vol. 1:473479.

REDUZOBOV, D.B. 1954. Thermal field laws of the permafrost in the Vorkuta region. Trudy Instituta merzlotovedeniia. In: Obrucheva, V.A. Akademica Nauk SSSR, Vol. 1 (1946). (Translated by Leonid Stambulsheik and Jaroslav Jan Peel, SIPRE. Translation 17).

SANGER, F.J. 1966. Degree-days and heat conduction in soils. In: Permafrost: Proceedings of an International Conference. Washington, D.C.: National Academy of Sciences. 253-262.

SMITH, M.H. 1975. Microclimatic influences on ground temperatures and permafrost distribution, Mackenzie Delta, Northwest Territories. Canadian Journal of Earth Sciences 12:1421-1438.

THOMPSON, H.A. 1966. Air temperature in northern Canada with emphasis on freezing and thawing indexes. In: Permafrost: Proceedings of an International Conference. Washington, D.C.: National Academy of Sciences. 272-280.

TROLL, C. 1943. Die Frostwechselhäufigkeit in den Luft - und Bodenclimaten der Erde. Meteorologische Zeitschrift 60:161-171.

WASHBURN, A.L. 1973. Periglacial Processes and Environments. London: E. Arnold Ltd. 320 p.

ZOLTAI, S.C. 1971. Southern limit of permafrost features in peat landforms, Manitoba and Saskatchewan. Geological Association of Canada Special Paper No. 9:305-310. 